\title{
Strong cellulase inhibitors from the hydrothermal pretreatment of wheat straw
}

\author{
Riin Kont, Mihhail Kurašin, Hele Teugjas and Priit Väljamäe*
}

\begin{abstract}
Background: The use of the enzymatic hydrolysis of lignocellulose with subsequent fermentation to ethanol provides a green alternative for the production of transportation fuels. Because of its recalcitrant nature, the lignocellulosic biomass must be pretreated before enzymatic hydrolysis. However, the pretreatment often results in the formation of compounds that are inhibitory for the enzymes or fermenting organism. Although well recognized, little quantitative information on the inhibition of individual cellulase components by identified inhibitors is available.

Results: Strong cellulase inhibitors were separated from the liquid fraction of the hydrothermal pretreatment of wheat straw. HPLC and mass-spectroscopy analyses confirmed that the inhibitors were oligosaccharides (inhibitory oligosaccharides, IOS) with a degree of polymerization from 7 to 16. The IOS are composed of a mixture of xylo- (XOS) and gluco-oligosaccharides (GOS). We propose that XOS and GOS are the fragments of the xylan backbone and mixed-linkage $\beta$-glucans, respectively. The IOS were approximately 100 times stronger inhibitors for Trichoderma reesei cellobiohydrolases (CBHs) than cellobiose, which is one of the strongest inhibitors of these enzymes reported to date. Inhibition of endoglucanases (EGs) by IOS was weaker than that of CBHs. Most of the tested cellulases and hemicellulases were able to slowly degrade IOS and reduce the inhibitory power of the liquid fraction to some extent. The most efficient single enzyme component here was T. reesei EG TrCel7B. Although reduced by the enzyme treatment, the residual inhibitory power of IOS and the liquid fraction was strong enough to silence the major component of the $T$. reesei cellulase system, CBH TrCel7A.

Conclusions: The cellulase inhibitors described here may be responsible for the poor yields from the enzymatic conversion of the whole slurries from lignocellulose pretreatment under conditions that do not favor complete degradation of hemicellulose. Identification of the inhibitory compounds helps to design better enzyme mixtures for their degradation and to optimize the pretreatment regimes to minimize their formation.
\end{abstract}

Keywords: Cellulase, Cellulose, Lignocellulose, Hydrothermal pretreatment, Hemicellulose, Xylooligosaccharides, Inhibition, Cellobiohydrolase, Bioethanol, Trichoderma reesei

\section{Background}

Lignocellulose is the most abundant biopolymer on the Earth and has a significant potential as a renewable energy source. Therefore, the use of cellulosic biomass for the production of ethanol that can replace oil-based transportation fuels is currently being researched intensively [1]. The complex structure of lignocellulose consists of three primary components: cellulose, hemicellulose, and lignin $[2,3]$. The main component of plant cell walls, cellulose, consists of linear $\beta$-1,4-glucan chains that adhere to each

\footnotetext{
*Correspondence: priit.valjamae@ut.ee

Institute of Molecular and Cell Biology, University of Tartu, Riia 23b - 202, 51010 Tartu, Estonia
}

(c) 2013 Kont et al.; licensee BioMed Central Ltd. This is an Open Access article distributed under the terms of the Creative Commons Attribution License (http://creativecommons.org/licenses/by/2.0), which permits unrestricted use, distribution, and reproduction in any medium, provided the original work is properly cited. other, forming crystalline higher-order fibrous structures. Hemicellulose includes a number of polysaccharides that vary in sugar composition, types of linkages, branching, and substitutions. Different plants, such as woody plants and grasses, have different hemicellulose compositions, and therefore, different classifications of hemicelluloses have been used [4]. Hemicelluloses in cereals are often divided into four groups: (i) xylans, (ii) mannans, (iii) xyloglucans, and (iv) mixed-linkage $\beta$-glucans [5]. Xylan, the main hemicellulose in hardwoods and annual plants, consists of a linear backbone of $\beta$-1,4-linked xylopyranose $(\mathrm{Xyl})$ residues. The latter are often substituted at its 2-O and/or 3-O with arabinose (Ara), glucuronic acid, and 
acetic acid [6]. Glucomannan, the most abundant hemicellulose in softwoods, consists of a $\beta$-1,4-linked mannose and glucose backbone that is substituted with $\alpha$-galactose. The backbone of xyloglucan consists of $\beta$-1,4-linked glucose residues, over half of which are substituted with $\alpha$-linked Xyl residues. Mixed-linkage $\beta$-glucans consist of $\beta$-1,3-linked segments of $\beta$-1,4-linked glucose residues and are characteristic of the Poales, including cereals. Glucose residues in mixed-linkage $\beta$-glucans are not substituted [5,7]. In plant cell walls, cellulose elementary fibrils are associated with hemicellulose, forming a complex network of polysaccharides, which is in turn embedded in the matrix of lignin [3].

The most efficient lignocellulose degraders in nature are fungi. They secrete a number of enzymes involved in cellulose, hemicellulose, and lignin breakdown. These enzymes are collectively referred to as the lignocellulolytic system [8]. The best-characterized cellulolytic system is that of the soft rot fungus Trichoderma reesei. The most abundant cellulase of $T$. reesei is cellobiohydrolase $(\mathrm{CBH})$, $\operatorname{TrCel7A}$, which constitutes approximately $60 \%$ of the secreted enzymes. $\operatorname{TrCel7} \mathrm{A}$ is also a major component of many commercial cellulase preparations. Another $\mathrm{CBH}$, $\operatorname{TrCel6A}$, constitutes approximately $20 \%$ of the enzymes secreted by $T$. reesei. Beside two CBHs, T.reesei also secretes a number of endoglucanases (EGs), including $\operatorname{Tr}$ Cel7B, $\operatorname{Tr}$ Cel5A, and $\operatorname{Tr}$ Cel12A, and enzymes involved in hemicellulose degradation. The main product of cellulose hydrolysis is cellobiose, which is also a strong inhibitor for CBHs. Therefore, the cellulolytic systems also contain $\beta$-glucosidase, an enzyme that hydrolyses cellobiose into two molecules of glucose.

Owing to its function in plant cell walls, lignocellulose has evolved into a structure that makes it recalcitrant toward chemical and enzymatic breakdown [9]. Therefore, a physicochemical pretreatment of biomass is necessary before enzymatic hydrolysis [10,11]. Pretreatment opens up the plant cell wall structure and improves the access of enzymes to cellulose. In the lignocellulose-to-ethanol process, the pretreated biomass is subjected to enzymatic hydrolysis, followed by fermentation of the resulting soluble sugars to ethanol. Depending on the conditions used, the pretreatments can be broadly divided into alkali, acid, organosolv, and hydrothermal pretreatments. Alkali and organosolv pretreatments are effective in removing lignin, whereas the hemicellulose is not degraded. Acid and hydrothermal pretreatments result in alteration of the structure of lignin and its relocation. Depending on the severity of the pretreatment $(\mathrm{pH}$, temperature, and residence time), acid and hydrothermal pretreatments result in the partial or complete hydrolysis of hemicellulose [11]. Because there is no addition of chemicals, hydrothermal pretreatments provide a green route for the pretreatment of biomass and are employed in many operational lignocellulose-to-ethanol pilot units around the world [12-14]. During hydrothermal pretreatment, most of the hemicellulose is solubilized through the fragmentation to oligosaccharides and ends up in the liquid fraction (LF) $[11,15]$. Although it has an altered structure, most of the lignin remains associated with cellulose and stays in the solid fraction $[11,16]$. Various low-molecular-weight degradation products of hemicellulose and lignin that have been shown to be inhibitory for yeast fermentation also concentrate in the LF [17]. Therefore, the LF is usually separated before the solid fraction is added to the hydrolysis and fermentation tanks. The separated LF can be used in different ways, e.g., in the Inbicon process, the oligosaccharide-rich LF is used for the production of animal feed. However, to maximize ethanol yields from biomass, there is a strong interest in using whole slurries from pretreatment rather than separated solid fractions. This has led to an intensive search for inhibitor-tolerant microorganisms and to the engineering of microorganisms to have a better tolerance for biomass-derived inhibitors [17-19]. Besides inhibitors for fermentation, the pretreatment can also result in the formation of compounds that are inhibitory for the enzymatic hydrolysis of pretreated biomass [20-25]. However, quantitative studies of the inhibition of cellulases by biomass-derived isolated inhibitors are scarce [23]. Previously, we developed a ${ }^{14} \mathrm{C}$-labeled cellulose-based method to characterize the product inhibition of cellulases [26]. In this study, we employ these methods to characterize strong cellulase inhibitors from the LF of the hydrothermal pretreatment of wheat straw. The inhibitors were oligosaccharides, and they were approximately 100 times stronger inhibitors for $T$. reesei cellulases than cellobiose, one of the most potent cellulase inhibitors described to date.

\section{Results and discussion}

\section{$\mathrm{CBH} \operatorname{TrCel7A}$ is strongly inhibited by the liquid fraction} from the hydrothermal pretreatment of wheat straw

The hydrothermal pretreatment of wheat straw was conducted in the Inbicons pilot plant in Skærbæk, Fredericia, Denmark $[12,13,16]$. Presoaked wheat straw was treated with pressurized water at $195^{\circ} \mathrm{C}$ for $12 \mathrm{~min}$ at a water-straw ratio of 5:1. The resulting slurry was separated into a solid and a liquid fraction (LF). In this way, $100 \mathrm{~kg}$ of wheat straw (on a dry matter, DM, basis) was converted into a $175 \mathrm{~kg}$ solid fraction (35\% DM) and a 400 liter LF (3\% DM). Approximately $80 \%$ of the total hemicellulose in wheat straw was solubilized during pretreatment, whereas most of the lignin and cellulose remained in the solid fraction (Table 1). The majority of the sugars in the LF were in the form of oligosaccharides, whereas the concentration of free monosaccharides was low (Table 2). To determine whether the pretreatment resulted in the formation of cellulase inhibitors, we tested the possible inhibition of 
Table 1 Composition of wheat straw and solid fraction from the pretreatment ${ }^{a}$

\begin{tabular}{llllll}
\hline & Cellulose & Xylan & Arabinan & Lignin & Ash \\
\hline Raw wheat straw & 36.4 & 23.5 & 2.9 & 20 & 4.7 \\
Pretreated wheat straw & 58.5 & 5.3 & Not detected & 26.4 & 2.6 \\
\hline
\end{tabular}

${ }^{a}$ The composition is given as a percentage of DM, and the carbohydrates are calculated as the anhydrous form. The composition was provided by Jan Larsen from Inbicon, Fredericia, Denmark.

the major component of commercial cellulase systems, $\operatorname{TrCel7A}$, by the LF using uniformly ${ }^{14} \mathrm{C}$-labeled bacterial cellulose $\left({ }^{14} \mathrm{C}\right.$ - $\left.\mathrm{BC}\right)$ as the substrate. Before use, the residual solids in the LF were removed by centrifugation and filtration of the supernatant. Because cellobiose is a strong inhibitor of TrCel7A [26-28] and the LF may contain some cellobiose, the LF was also treated with $\beta$-glucosidase purified from Novozymes ${ }^{\circ} 188$ (N188BG). Supplementation of the hydrolysis mixture with $40 \%$ of the N188BGtreated LF resulted in more than $90 \%$ inhibition of the synergistic hydrolysis of ${ }^{14} \mathrm{C}$ - $\mathrm{BC}$ by the mixture of $\operatorname{Tr}$ Cel7 A and EG, $\operatorname{TrCel} 5 \mathrm{~A}$. Treatment of the LF with $2 \%$ sulfuric acid at $121^{\circ} \mathrm{C}$ for $20 \mathrm{~min}$, which is the standard procedure used to hydrolyze oligosaccharides to their monosaccharide components, significantly reduced the inhibitory power of the LF, suggesting that the inhibitory species may be oligosaccharides (Figure 1A). The inhibition of $\operatorname{TrCel7A}$ by the LF was also tested using methylumbelliferyl- $\beta$-lactoside (MUL) as a substrate. An approximately 10,000-fold dilution of the LF added to the reaction mixture resulted in a $50 \%$ decrease in the hydrolysis rate of MUL. Treatment of the LF with N188BG decreased its inhibitory power against $\operatorname{TrCel7A}$ approximately two-fold (Figure $1 \mathrm{~B})$. Inhibition of $\operatorname{TrCel7A}$ [29] and other cellulases [21,22,30,31] by xylooligosaccharides (XOS) is well recognized. However, the inhibition of $\operatorname{TrCel7A}$ by LF was stronger than one may deduce from the concentration of xylose in the oligosaccharide fraction of the LF (Table 2) and the reported inhibitory strengths for XOS [29]. This prompted us to further study the nature of the inhibitory compounds in the LF.

\section{Identification of the inhibitors from the liquid fraction}

Size exclusion chromatography (SEC) was chosen as the first step in the isolation of inhibitory compounds from the LF. Fractions were analyzed for the reducing groups and inhibitory strength against $\operatorname{TrCel7A}$. Inhibitory strength eluted over a large volume, indicating that the mixture of different species spanning the molecular weight range of approximately $0.5-10 \mathrm{kDa}$ is responsible for the inhibition (Figure 2). The SEC fractions were further analyzed by HPLC. The fractions from HPLC were also tested for the reducing groups and inhibitory strength against $\operatorname{TrCel7A}$. Inhibitory strength was observed in a dominating peak that eluted well before mono and disaccharide standards. Because HPLC analysis of the SEC fractions corresponding to $\mathrm{Mw}$ values of $3 \mathrm{kDa}$ and above revealed more heterogeneous material with inhibitory strength, we further focused on the SEC fractions corresponding to the Mw range of $1 \mathrm{kDa}-3 \mathrm{kDa}$ (Figure 2). These fractions were concentrated in a vacuum evaporator and purified using HPLC (Figure 3A). HPLC purification resulted in an approximately 3 -fold increase in inhibitory strength on a reducing group basis. The HPLC purified material was used in further inhibition studies and is referred to as inhibitory oligosaccharides (IOS) throughout the study. The treatment of IOS with $2 \%$ sulfuric acid at $121^{\circ} \mathrm{C}$ before the HPLC analysis revealed that IOS consisted of xylose (Xyl) and glucose (Glc) in the molar ratio of 5/1 (Figure 3B). Other monosaccharide components present in the LF (Table 2) were not detected in IOS. Electrospray ionization mass spectrometry (ESI-MS) analysis confirmed that IOS consisted of a heterogeneous mixture of oligosaccharides with different degrees of acetylation and Mw-s ranging from $1.0 \mathrm{kDa}$ to $3.0 \mathrm{kDa}$ (Figure 4A). Although Xyl and Glc cannot by identified by ESI-MS, the pentoses and hexoses are referred to here as Xyl and Glc to be consistent with the HPLC analysis (Figure 3B). Because the mass of the $\mathrm{Xyl}_{4}$ unit equals the mass of $\mathrm{Glc}_{3} \mathrm{Ac}_{1}$, the deacetylation of IOS was necessary to reveal the composition of oligosaccharide components. The removal of acetyl groups by alkaline treatment revealed that IOS was a mixture of XOS and glucooligosaccharides (GOS) with DP ranging from 7 to 16 (Figure 4B). Comparison of the ESI-MS spectrums of original and deacetylated IOS demonstrated that XOS were acetylated to a different extent, whereas GOS were not.

IOS in the LF apparently originate from the hemicellulose in wheat straw, which is fragmented during hydrothermal pretreatment. XOS originate from the xylans that are abundant components of the hemicellulose in cereals [32].

Table 2 Composition $\left(\mathrm{g} \mathrm{I}^{-1}\right)$ of the liquid fraction from the pretreatment of wheat straw ${ }^{\mathrm{a}}$

\begin{tabular}{llllll}
\hline & Glucose & Xylose & Arabinose & Galactose & Mannose \\
\hline Total sugars & 3.4 & 11.3 & 1.2 & 0.8 & 0.8 \\
Free monomeric sugars & 0.4 & 2.6 & 0.6 & 0.2 & 0.2 \\
Sugars in oligosaccharides $^{b}$ & 3.0 & 8.7 & 0.6 & 0.6 & 0.6 \\
\hline
\end{tabular}

${ }^{a}$ The composition was provided by Jan Larsen from Inbicon, Fredericia, Denmark.

${ }^{\mathrm{b}}$ Found as a difference between total and free monomeric sugars. 


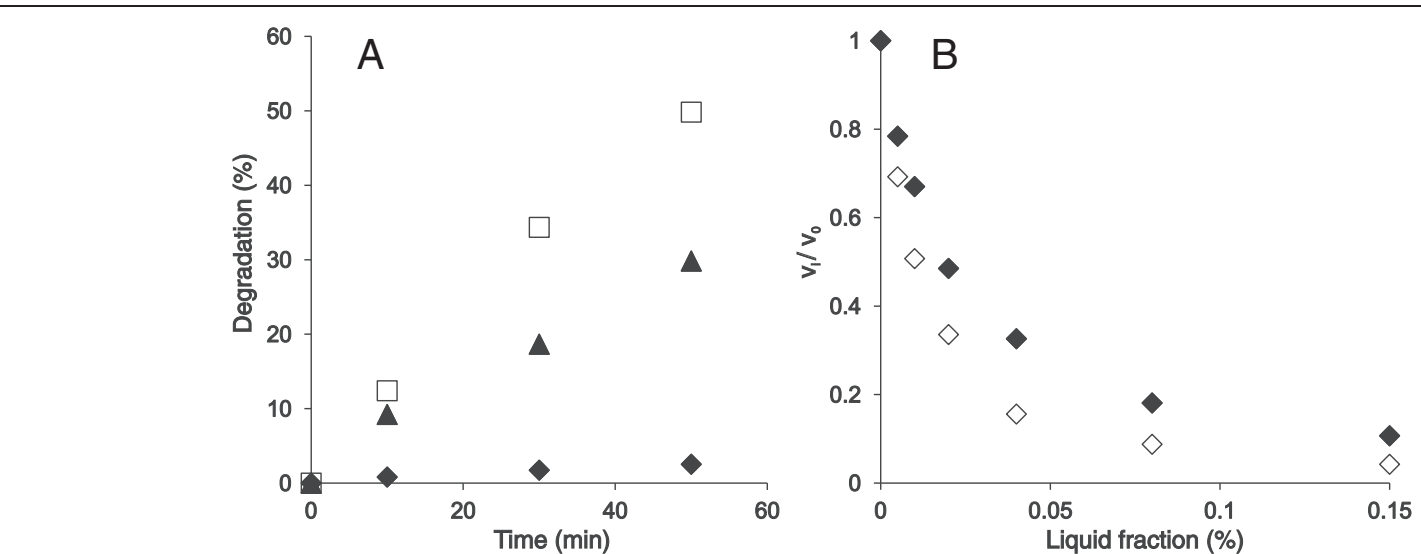

Figure 1 The $\mathrm{LF}$ is a strong inhibitor for $\operatorname{TrCel7A}$ on both ${ }^{14} \mathrm{C}-\mathrm{BC}$ and MUL substrates. $(\mathbf{A}){ }^{14} \mathrm{C}-\mathrm{BC}\left(0.25 \mathrm{mg} \mathrm{ml}^{-1}\right)$ was incubated with the mixture of $0.25 \mu \mathrm{M}$ TrCel7A, $0.025 \mu \mathrm{M}$ EG (TrCel5A), and $0.1 \mu \mathrm{M}$ N188BG at $25^{\circ} \mathrm{C}$ in the presence of no LF (口), N188BG-treated LF ( $)$ ), or sulfuric acid-treated LF ( $\mathbf{\Delta})$. (B) MUL $(5 \mu \mathrm{M})$ was incubated with $10 \mathrm{nM} \operatorname{TrCel7A}$ at $35^{\circ} \mathrm{C}$ in the presence of the original LF $(\diamond)$ or the N188BG-treated LF ( $)$.

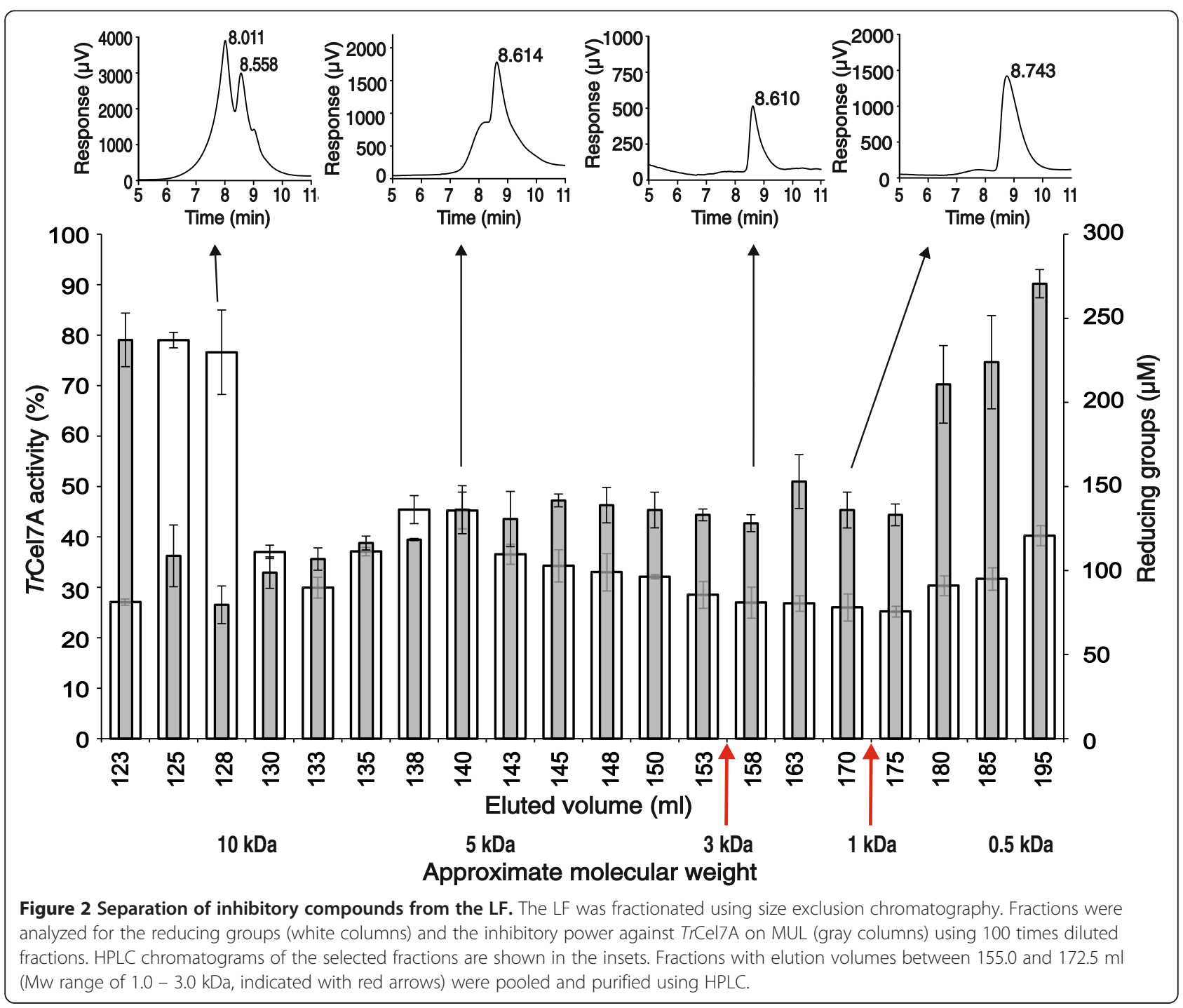



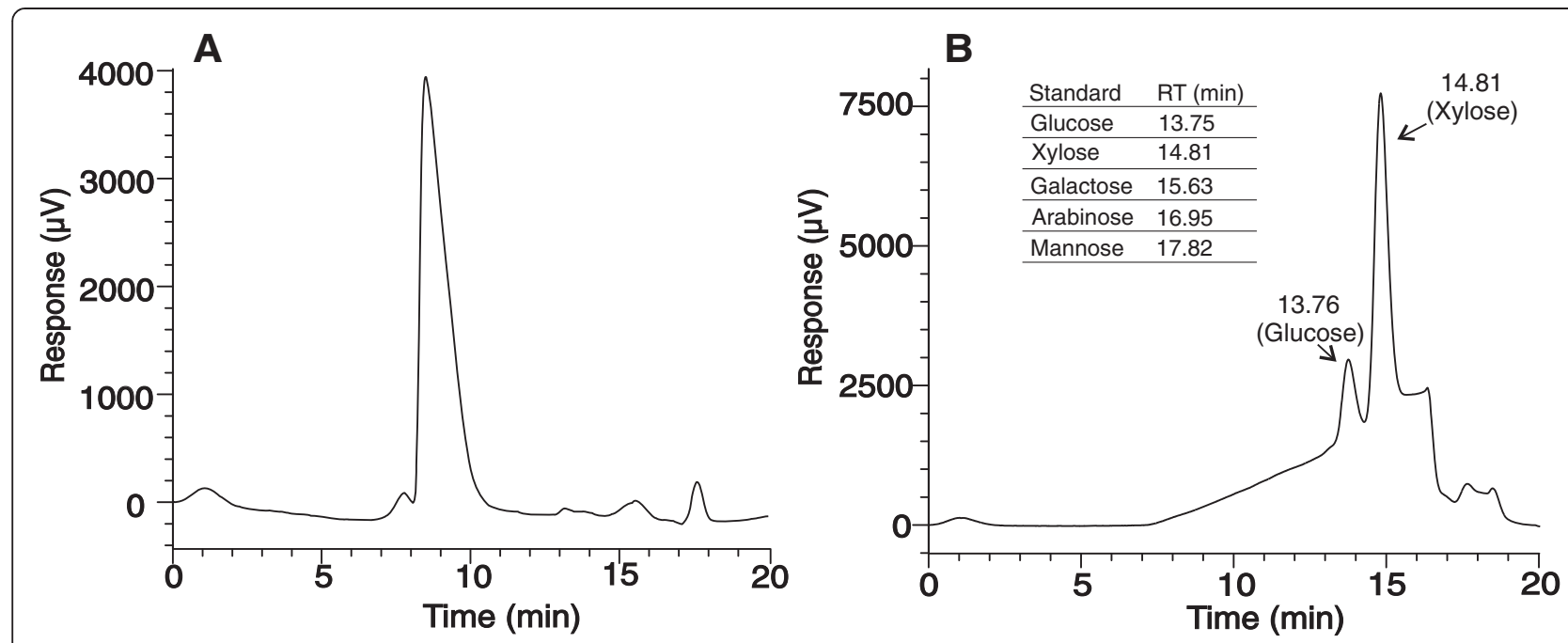

Figure 3 Determination of the monosaccharidic composition of IOS isolated from LF. (A) HPLC chromatogram of IOS purified from the pooled SEC fractions (region between the red lines in Figure 2). (B) The HPLC chromatogram of sulfuric acid-treated IOS reveals that IOS was composed of xylose and glucose in the molar ratio of 5/1.

Because branches in the xylans start with Ara or glucuronic acid, which were not detected in IOS, the XOS are apparently the fragments of the xylan backbone that consists of a linear chain of $\beta$-1,4-linked xylopyranose residues. The absence of Ara in IOS also suggests that those Ara substitutions of the xylan backbone that were not removed during the hydrothermal pretreatment (Table 2) remained in the SEC fractions not included in the purification of IOS. The origin of GOS is not as obvious as that of XOS. GOS may be fragments of cellulose, but this is opposed by the insolubility of cellooligosaccharides with a DP above 7 [33]. We propose that GOS are fragments of mixed-linkage $\beta$-glucans, homopolymers of glucose in which the blocks of $\beta-1,4$-linked glucose molecules are linked together through $\beta-1,3$ linkages. The number of glucose units in $\beta-1,4$-linked segments is usually 3 or 4 but may be as high as 15 [34]. Unlike solely $\beta$-1,4-containing cellooligosaccharides, the mixed-linkage $\beta$-glucans have been demonstrated to be soluble [32,34]. The proposed structures of XOS and GOS are shown in Figure 5. Determination of the exact structure of XOS and GOS remained beyond the scope of the present study.

\section{Inhibition of cellulases by IOS}

Here, we characterize the main T. reesei cellulases along with N188BG in terms of inhibition by IOS using both low $\mathrm{Mw}$ model substrates and ${ }^{14} \mathrm{C}$-labeled cellulose substrates. The concentration of IOS was expressed on a reducing group basis. Reducing groups were measured using the modified bicinchoninic acid (BCA) method, which has been shown to be independent of the DP of oligosaccharides [33]. Calibration curves made with glucose and xylose standards also gave the same response using the
BCA method. First, we assessed the type of IOS inhibition of $\operatorname{Tr}$ Cel7A using para-nitrophenyl- $\beta$-lactoside (pNPL) as a substrate. Consistent with competitive inhibition, the presence of IOS resulted in increased $K_{\mathrm{M}}$ values of $\operatorname{Tr} \mathrm{Cel} 7 \mathrm{~A}$ for $\mathrm{pNPL}$, whereas the catalytic constant remained unaffected. In further studies, we used a simplified approach and measured the $I C_{50}$ value for IOS at one substrate concentration. Provided that the inhibition is competitive and the substrate concentration is well below its $K_{\mathrm{M}}$, the resulting $I C_{50}$ is close to the value of the true inhibition constant, $K_{\mathrm{i}}$ (Equation 1) [26].

$$
I C_{50}=K_{i}\left(1+\frac{[S]}{K_{M}}\right)
$$

First, the inhibition of $\operatorname{TrCel7A}$ on $5 \mu \mathrm{M}$ MUL $\left(K_{\mathrm{M}}\right.$ of $\operatorname{Tr}$ Cel7A for MUL is approximately $300 \mu \mathrm{M}$ [35]) was studied. The IOS inhibited $T r$ Cel7 A with an $I C_{50}$ value of $0.31 \pm 0.03 \mu \mathrm{M}$, whereas the $I C_{50}$ for cellobiose inhibition was $36 \pm 6 \mu \mathrm{M}$ (Figure 6A). Thus, IOS were approximately 100-fold stronger inhibitors for $\operatorname{Tr}$ Cel7A than cellobiose, which is one of the most potent inhibitors of $\operatorname{TrCel7A}$ described to date. IOS were also much stronger inhibitors than cellobiose for EG $\operatorname{Tr}$ Cel7B (Figure $6 \mathrm{~B}$ ). An $I C_{50}$ value of $30 \pm 5 \mu \mathrm{M}$ was found for IOS inhibition of $\operatorname{TrCel7B}$ acting on $20 \mu \mathrm{M}$ MUL, whereas the $I C_{50}$ for cellobiose inhibition was $8.9 \pm 0.4 \mathrm{mM}$. The hydrolysis of MU-glucose by N188BG was not inhibited by IOS up to $100 \mu \mathrm{M}$, the highest concentration of IOS tested.

The inhibition strength of cellulases measured on lowMw model substrates does not necessarily reflect the inhibition strength on cellulose substrates [26]. Therefore, we also assessed the IOS inhibition of cellulases acting 


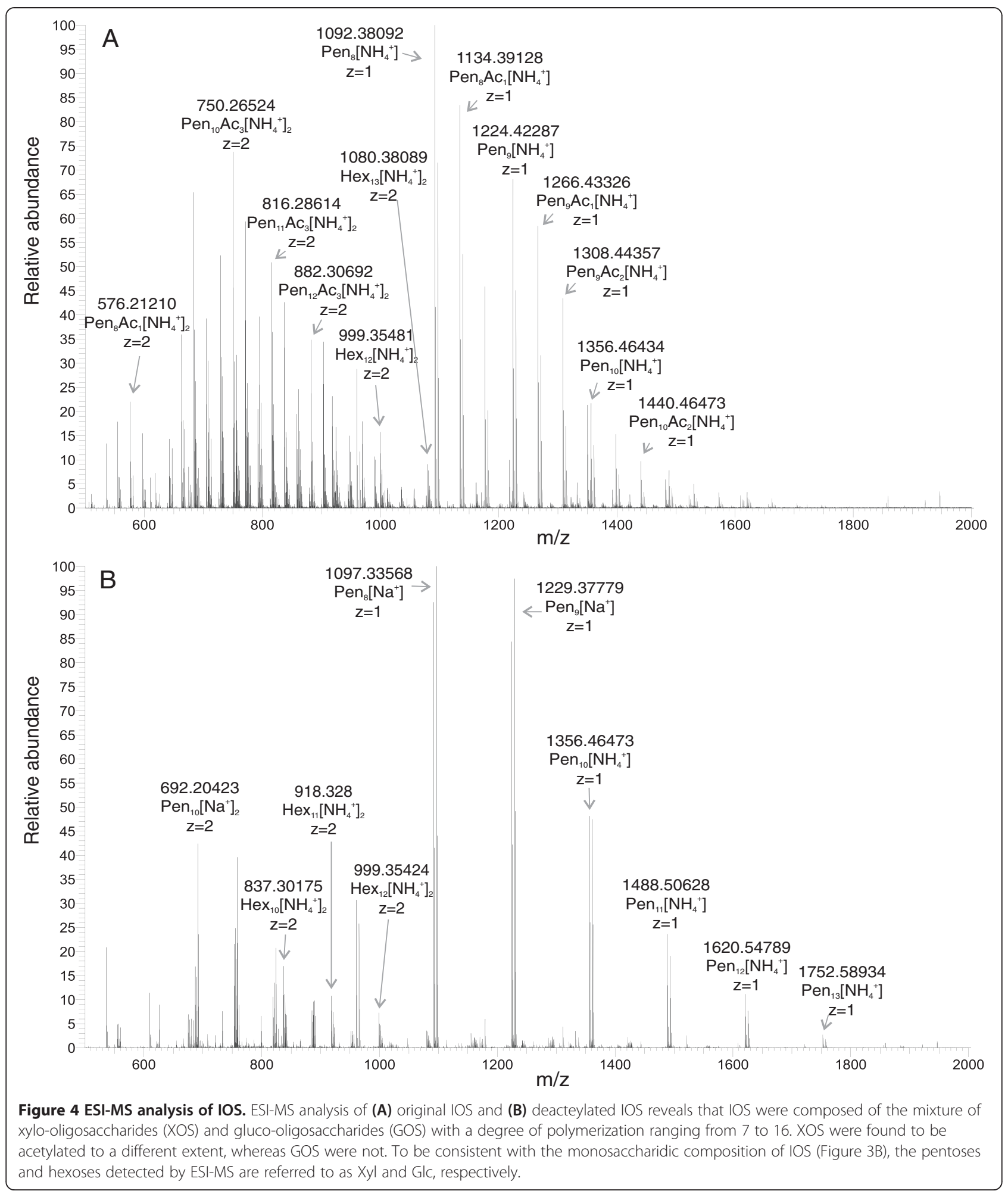

on ${ }^{14} \mathrm{C}$-labeled celluloses. Strong interactions between XOS and cellulose are well known [36-40]. Possible sequestering of IOS by cellulose may decrease their availability as inhibitors for cellulases and lead to an underestimation of their inhibitory strength. Therefore, the binding of
IOS to ${ }^{14} \mathrm{C}$-celluloses was assessed before inhibition studies. Cellulose was mixed with IOS, and after $30 \mathrm{~min}$ of incubation, cellulose was separated by centrifugation. The concentration of free IOS in the supernatant ([IOS $\left.]_{\text {free }}\right)$ was measured from the inhibitory strength against $\operatorname{Tr} \mathrm{Cel} 7 \mathrm{~A}$ 


$$
\text { A }
$$

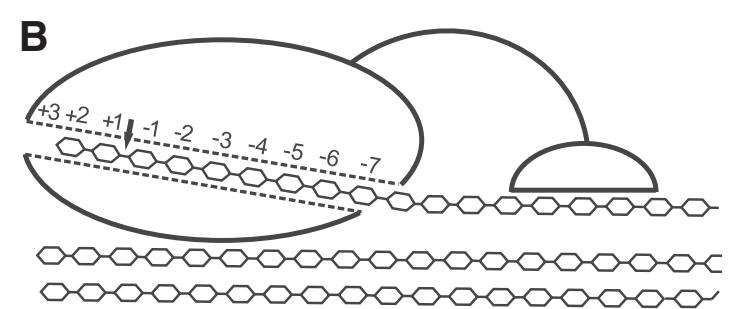

Figure 5 Possible structures of IOS provide a mechanistic interpretation of the strong inhibition of TrCel7A. (A) We propose that component oligosaccharides of IOS, XOS and GOS, are the fragments of the xylan backbone and mixed linkage b-glucan, respectively. (B) XOS and GOS mimic the structure of cellulose chain and bind to the active site tunnel of TrCel7A through all 10 glucose unit binding sites. This results in stronger binding than that of cellobiose, which binds to the product sites $(+1 /+2)$ only.

on MUL using the previously quantified $I C_{50}$ value of $0.31 \mu \mathrm{M}$ and the equation for competitive inhibition in the conditions of $[\mathrm{MUL}]<<K_{\mathrm{M}(\mathrm{MUL})}$ :

$$
[I O S]_{\text {free }}=I C_{50}\left(\frac{v_{0}}{v_{i}}-1\right)
$$

$v_{\mathrm{i}}$ and $v_{0}$ are the initial rates of MUL hydrolysis measured in the presence and absence of IOS containing supernatants, respectively. Thus, what is measured here is the binding of the inhibitory strength against $\operatorname{TrCel7A}$ to cellulose. The distribution between the free and cellulose-bound inhibitory strength of IOS is shown in Figure 7A. The binding of IOS to cellulose followed the Langmuir isotherm. For ${ }^{14} \mathrm{C}-\mathrm{BC}$, the maximum binding capacity of $42 \mu \mathrm{mol}$ IOS $\mathrm{g}^{-1}$ cellulose with $15 \mu \mathrm{M}$ half saturating $[\mathrm{IOS}]_{\text {free }}$ was found. The binding capacity of IOS to the ${ }^{14} \mathrm{C}$-amorphous cellulose was approximately 4 times lower than that to ${ }^{14} \mathrm{C}-\mathrm{BC}$ (Figure 7A). This finding is paralleled by a recent report of the stronger binding of hemicelluloses to $\mathrm{BC}$ than to amorphous cellulose [41]. The $[\mathrm{IOS}]_{\text {free }}$ was used rather than the total concentration of IOS in further inhibition studies. For the inhibition of
$\operatorname{TrCel7A}$, the time courses of the synergistic hydrolysis of ${ }^{14} \mathrm{C}$-BC by the mixture of $\operatorname{TrCel7} \mathrm{A}$ and EG, $\operatorname{TrCel} 5 \mathrm{~A}$ (10\% on a mole basis), in the presence of IOS was followed (Additional file 1: Figure S1A). The strength of inhibition was analyzed using the plots in coordinates $\left(\mathrm{D}_{\mathrm{IOS}} / \mathrm{D}_{\mathrm{IOS}=0}\right)$ versus $[\mathrm{IOS}]$, where $\mathrm{D}_{\mathrm{IOS}}$ and $\mathrm{D}_{\mathrm{IOS}=0}$ represent the degree of conversion of ${ }^{14} \mathrm{C}$ - $\mathrm{BC}$ in the presence and absence of IOS, respectively (Figure 7B). Because the inhibition of $\operatorname{TrCel7A}$ by cellobiose released during cellulose hydrolysis was significant, it was accounted for in calculating the $I C_{50}$ values of IOS inhibition.

$$
\frac{D_{I O S}}{D_{I O S=0}}=\frac{\left(\left[{ }^{14} C B C\right]+C_{1}\right)(1-H)}{\left[{ }^{14} C B C\right]+C_{1}\left(1+\frac{[C B]}{I C_{50(C B)}}+\frac{[I O S]_{\text {free }}}{C_{2}}\right)}+H
$$

[CB] is the concentration of cellobiose released during hydrolysis, $\left[{ }^{14} \mathrm{CBC}\right]$ is the concentration of ${ }^{14} \mathrm{C}-\mathrm{BC}$ used in the experiment, and $I C_{50(\mathrm{CB})}$ is the $I C_{50}$ for cellobiose (its value was fixed to $0.68 \mathrm{mM}$, Table 3 ). The values of constants $C_{1}, C_{2}$, and $H$ obtained by the fitting of the
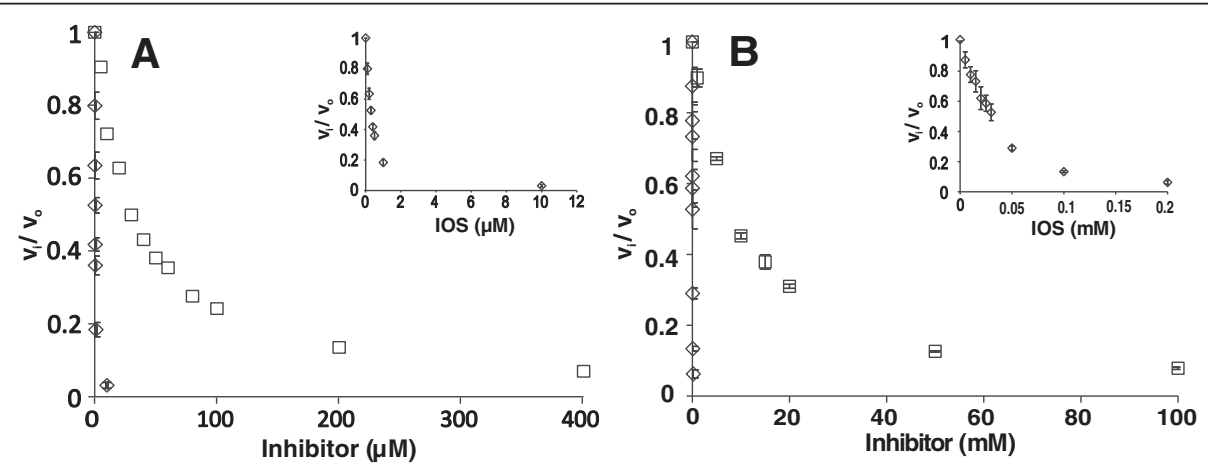

Figure 6 Cellobiose and IOS inhibition of $\operatorname{TrCel7A}$ and $\operatorname{TrCel7B}$ on MUL. Initial rates of MUL hydrolysis by (A) CBH $\operatorname{TrCel7A}$ or (B) EG $\operatorname{TrCel7B}$ were measured in the absence $\left(v_{0}\right)$ and presence $\left(v_{i}\right)$ of the inhibitor at the indicated concentrations. The inhibitor was either cellobiose ( $\square$ ) or IOS ( $)$. Experiments were performed in $50 \mathrm{mM}$ sodium acetate buffer, $\mathrm{pH} 5.0$, containing BSA $\left(0.1 \mathrm{gl}^{l^{-1}}\right)$ at $35^{\circ} \mathrm{C}$. 

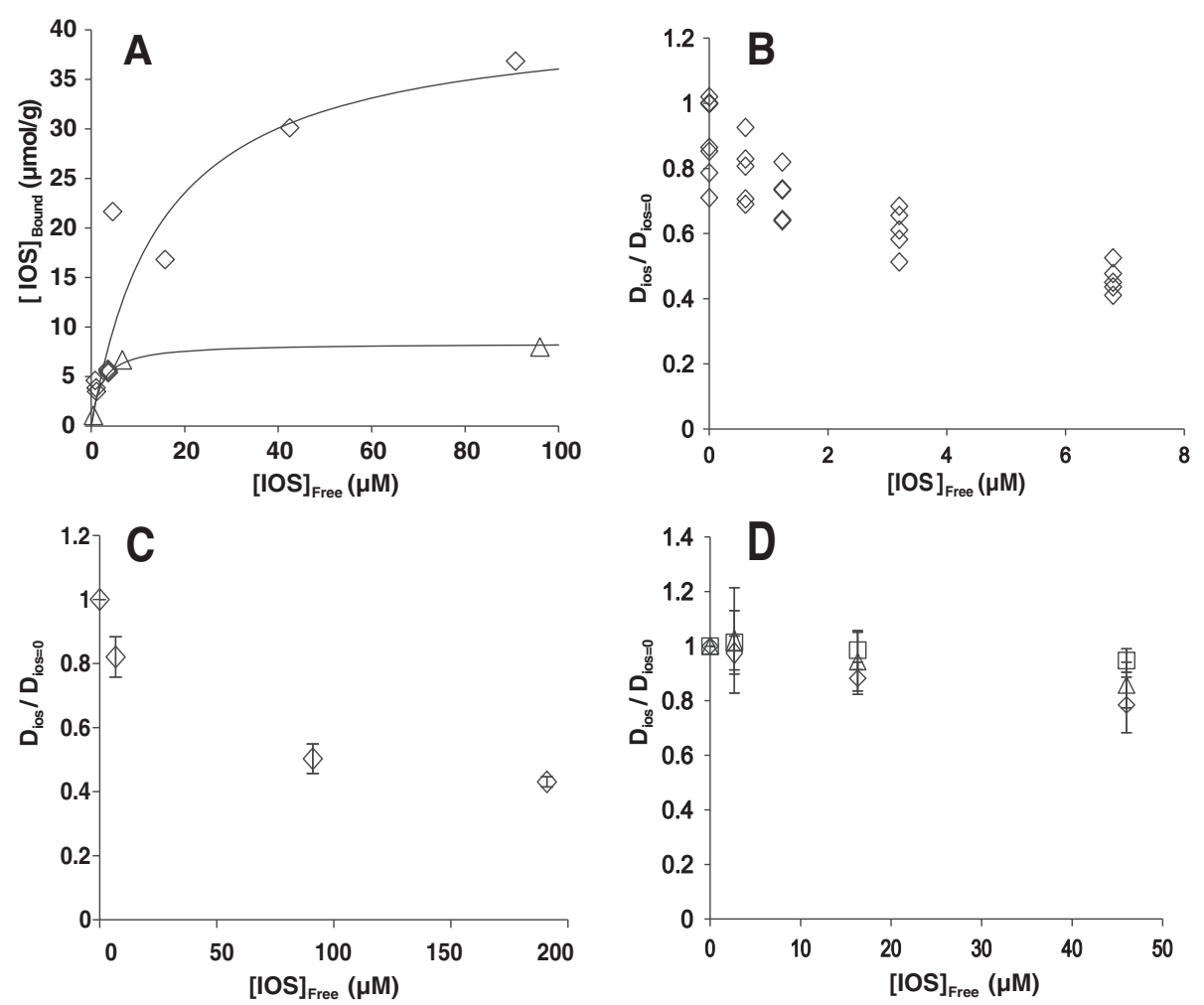

Figure $7 \mathrm{IOS}$ inhibition of $T$. reesei cellulases on ${ }^{14} \mathrm{C}$-cellulose substrates. (A) Binding of IOS to ${ }^{14} \mathrm{C}-\mathrm{BC}\left(0.25 \mathrm{~g} \mathrm{l^{-1 }}\right)(\boldsymbol{\vartheta})$ or ${ }^{14} \mathrm{C}$-amorphous cellulose $\left(0.5 \mathrm{~g} \mathrm{I}^{-1}\right)(\Delta)$. IOS $\left(0-100 \mu \mathrm{M}\right.$ on a reducing groups basis) were incubated with ${ }^{14} \mathrm{C}$-cellulose in $50 \mathrm{mM}$ sodium acetate buffer, $\mathrm{pH} 5$, containing BSA $\left(0.1 \mathrm{~g} \mathrm{I}^{-1}\right)$ at $35^{\circ} \mathrm{C}$ for $30 \mathrm{~min}$. Cellulose was separated by centrifugation, and the concentration of free IOS in the supernatant ([IOS $]_{\text {free }}$ ) was calculated from the inhibitory strength against TrCel7A on MUL using the $I_{50}$ value of $0.31 \mu \mathrm{M}$ and equation 2 . The concentration of IOS bound to cellulose ([IOS $]_{\text {bound }}$ ) was found as the difference between the total concentration of IOS and [IOS $]_{\text {free }}$. The solid lines are from the nonlinear regression analysis according to the Langmuir isotherm. (B) IOS inhibition of the synergistic hydrolysis of ${ }^{14} \mathrm{C}-\mathrm{BC}$ by the mixture of CBH TrCel7A and EG TrCel5A. In the case of the absence of IOS, the reaction mixture also contained N188BG. (C) IOS inhibition of the hydrolysis of ${ }^{14} \mathrm{C}-\mathrm{BC}$ by CBH TrCel6A. (D) IOS inhibition of the hydrolysis of ${ }^{14} \mathrm{C}$-amorphous cellulose by EG TrCel7B ( () ), $\operatorname{TrCel} 5 \mathrm{~A}(\square)$, or $\operatorname{TrCel12A}(\triangle)$. All experiments were made in $50 \mathrm{mM}$ sodium acetate buffer, $\mathrm{pH}$ 5.0, containing BSA $\left(0.1 \mathrm{~g} \mathrm{I}^{-1}\right)$ at $35^{\circ} \mathrm{C}$. DIOs and $D_{10 S=0}$ represent the degree of conversion of ${ }^{14} \mathrm{C}$-cellulose in the presence and absence of IOS, respectively. For the time courses measured in the presence and absence of IOS, see Additional file 1: Figure S1.

Table 3 Inhibition of cellulases on ${ }^{14} \mathrm{C}$-cellulose substrates by IOS and cellobiose

\begin{tabular}{lll}
\hline & \multicolumn{2}{c}{$\boldsymbol{C}_{\mathbf{5 0}}(\mathbf{m M})$} \\
\cline { 2 - 3 } Enzyme & IOS & Cellobiose $^{\mathbf{a}}$ \\
\hline TrCel7A $^{\mathrm{b}}$ & $0.0082 \pm 0.0018^{\mathrm{c}}$ & $0.68 \pm 0.24$ \\
$\operatorname{TrCel6A}^{\mathrm{b}}$ & $0.0126 \pm 0.0026^{\mathrm{d}}$ & \\
& $0.076 \pm 0.034^{\mathrm{c}}$ & $16 \pm 0.5$ \\
$\operatorname{TrCel7B}^{\mathrm{e}}$ & $0.093 \pm 0.033^{\mathrm{d}}$ & $168 \pm 2$ \\
\hline
\end{tabular}

${ }^{\mathrm{a} D a t a}$ for $35^{\circ} \mathrm{C}$ from [26].

${ }^{\mathrm{b}}$ Studied on ${ }^{14} \mathrm{C}-\mathrm{BC}$ as a substrate at $35^{\circ} \mathrm{C}$.

${ }^{c}$ Analyzed using the concentrations of IOS free from cellulose.

${ }^{\mathrm{d}}$ Analyzed using the total concentrations of IOS.

${ }^{\mathrm{e}}$ Studied on ${ }^{14} \mathrm{C}$-amorphous cellulose as a substrate at $35^{\circ} \mathrm{C}$.

${ }^{f_{B}}$ Because of the long extrapolation (Figure 7D), this is only an approximate value and must be treated with caution. data to Equation 3 were used to calculate the $I C_{50}$ for IOS according to Equation 4.

$$
I C_{50}=\frac{\left[{ }^{14} C B C\right]+C_{1}}{\frac{C_{1}}{C_{2}}(1-2 H)} .
$$

For more details of the calculation of $I C_{50}$ values, see [26]. As in the case of the MUL substrate, the IOS inhibition of the hydrolysis of ${ }^{14} \mathrm{C}-\mathrm{BC}$ by $\operatorname{Tr}$ Cel7 A was approximately 100 times stronger than the cellobiose inhibition (Table 3). IOS inhibition of another T. reesei $\mathrm{CBH}, \operatorname{Tr}$ Cel6A, was also assessed on the ${ }^{14} \mathrm{C}-\mathrm{BC}$ substrate (Figure $7 \mathrm{C}$ ). Here, the inhibition by cellobiose released during cellulose hydrolysis was not significant, and the term $[\mathrm{CB}] / I C_{50(\mathrm{CB})}$ was omitted from Equation 3 in the analysis of the data. Although $\operatorname{Tr}$ Cel6A was more resistant to IOS inhibition than $\operatorname{TrCel7A}$, the IOS were also 
approximately 100 times stronger inhibitors than cellobiose for $\operatorname{TrCel6A}$ (Table 3). For both $\operatorname{TrCel7A}$ and $\operatorname{TrCel6A}$, the inhibitory strength of IOS appeared somewhat weaker if the total concentration of IOS was used in analyses rather than the $[\mathrm{IOS}]_{\text {free }}$ (Table 3$)$. Inhibition of EGs, $\operatorname{TrCel7B}, \operatorname{TrCel} 5 \mathrm{~A}$, and $\operatorname{Tr}$ Cel12A was assessed on ${ }^{14} \mathrm{C}$-amorphous cellulose (Figure $\left.7 \mathrm{D}\right)$. For the time courses of the hydrolysis of ${ }^{14} \mathrm{C}$-celluoses in the presence and absence of IOS, see Additional file 1: Figure S1. The inhibition of EGs was much weaker than that of CBHs. The availability of IOS limited the highest concentration of IOS used, and this did not permit the calculation of

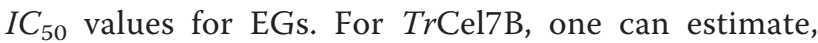
using long extrapolation, an apparent $I C_{50}$ value in the sub-millimolar range (Table 3). For $\operatorname{Tr}$ Cel5A and $\operatorname{Tr}$ Cel12A, it was not possible to say whether the enzymes were inhibited or not (Additional file 1: Figure S1). Similarly to cellobiose inhibition of these EGs [26,28], the most sensitive to IOS inhibition appeared to be $\operatorname{TrCel7B}$.

Inhibition of cellulose hydrolysis by polymeric xylans and by XOS is well known. For the mechanistic interpretation, at least two scenarios have been proposed: (i) by binding to the cellulose surface, xylans restrict the accessibility of cellulose to cellulases, and (ii) by binding to the active sites of cellulases, xylans compete with the binding of the cellulose chain. The first scenario is a plausible way to explain the mechanism of inhibition by polymeric xylans. Clear correlations between the cellulose digestibility and the amount of residual xylan on cellulose or between the degree of conversion of cellulose and xylan have been reported [20,42-46]. The second scenario has been primarily used to explain the inhibition of cellulases by XOS $[21,22,29,30,47]$. Because IOS were able to bind to cellulose (Figure 7A), the contribution of cellulose-bound IOS in inhibition cannot be excluded. The binding affinity of XOS to $\operatorname{Tr}$ Cel7A has been shown to increase with increasing DP of XOS [29]. The strongest binding to $\operatorname{Tr}$ Cel7A, with a $K_{\mathrm{d}}$ value of 3.4 $\mu \mathrm{M}$, reported to date is for the binding of a mixture $\mathrm{XOS}\left((\mathrm{Xyl})_{8} /(\mathrm{Xyl})_{9} /(\mathrm{Xyl})_{10}\right.$ in a $1 / 1 / 1$ ratio $)$ [29]. Because the active site of $\operatorname{TrCel7A}$ contains 10 glucose unit binding sites, the stronger binding of IOS observed here may be due to the higher DP of IOS. The mechanistic interpretation of the strong inhibitory power of IOS may be that, by mimicking the structure of the cellulose chain, XOS and GOS span the active site tunnel of $\operatorname{TrCel7A}$. By doing so, they can use the cumulative binding energy of all 10 glucose unit binding sites, whereas the binding of cellobiose relies primarily on interactions with the product binding sites $(+1 /+2)$ (Figure 5$)$.

\section{Enzymatic degradation of IOS}

Because hemicelluloses and their derivative oligosaccharides are expected to be the substrates for different cellulases [48], we also tested the possible enzymatic degradation of
IOS. Beside major T. reesei cellulases, a N188BG, xylanase TaXyn10A from Thermoascus aurantiacus [49], acetyl xylan esterase (TrAXE) from $T$. reesei [50], xyloglucanase ( $\operatorname{TrXG)}$ from $T$. reesei [51], and lichenase from Baccillus subtilis were tested for their ability to degrade IOS. IOS $(100 \mu \mathrm{M})$ were incubated with enzyme at $35^{\circ} \mathrm{C}$ for $2 \mathrm{~h}$. The residual inhibitory power of enzyme-treated IOS was assessed using the hydrolysis of MUL by $\operatorname{TrCel7A}$ as a reference reaction and is expressed as a percent of the inhibitory power of nontreated IOS against $\operatorname{TrCel7A}$ on MUL. The concentration of enzymes used in the treatment of IOS was selected so that they would mimic the approximate concentrations of enzymes used in the hydrolysis of lignocellulose under high DM consistency. As an example, if the hydrolysis of lignocellulose is conducted at 35\% $\mathrm{DM}$ and the total cellulase load is $5 \mathrm{mg} \mathrm{g}^{-1} \mathrm{DM}$, then the concentration of $\operatorname{TrCel7A}$ is approximately $20 \mu \mathrm{M}$ (considering that $\operatorname{TrCel7A}$ accounts for approximately $60 \%$ of the total cellulase and the $\mathrm{Mw}$ of the enzyme is $50 \mathrm{kDa}$ ). Because of this, a high concentration of enzymes was used for the treatment of IOS. All enzymes tested, except $\operatorname{TrAXE}$, were able to degrade IOS to a significant extent. The most efficient in reducing the inhibitory power of IOS were EGs $\operatorname{TrCel12A}$ and $\operatorname{TrCel7B}$ (Table 4). The relative efficiency of $\operatorname{Tr}$ Cel12A and $\operatorname{Tr}$ Cel7B in

Table 4 Residual inhibitory power of IOS and the LF after enzymatic treatment

\begin{tabular}{llll}
\hline & & \multicolumn{2}{l}{$\begin{array}{l}\text { Residual inhibitory } \\
\text { power }^{\mathbf{a}} \text { (\%) }\end{array}$} \\
\cline { 3 - 4 } Enzyme & Enzyme concentration & IOS $^{\mathbf{b}}$ & LF $^{\mathbf{c}}$ \\
\hline none & - & 100 & 100 \\
TrCel12A & $3.5 \mu \mathrm{M}$ & $3.0 \pm 0.8$ & $45 \pm 10$ \\
TrCel7B & $3.5 \mu \mathrm{M}$ & $3.8 \pm 0.3$ & $16 \pm 2$ \\
TaXyn10A & $1.75 \mu \mathrm{M}$ & $9.9 \pm 1.6$ & $85 \pm 4$ \\
TrCel5A & $3.5 \mu \mathrm{M}$ & $13.1 \pm 2.1$ & $43 \pm 1.4$ \\
TrCel7A & $21 \mu \mathrm{M}$ & $15.6 \pm 2.2$ & $55 \pm 9$ \\
TrCel6A & $7.0 \mu \mathrm{M}$ & $24.9 \pm 3.6$ & $49 \pm 8$ \\
N188BG & $1.75 \mu \mathrm{M}$ & $26.0 \pm 2.4$ & $49 \pm 9$ \\
Celluclast/N188 & $1.75 \mathrm{FPU} / \mathrm{ml}$ & n.d. ${ }^{\text {d }}$ & $6.9 \pm 0.6$ \\
& $4.55 \mathrm{CBU} / \mathrm{ml}$ & & \\
Thermomix & $2.8 \mathrm{mg} / \mathrm{ml}(1.8 \mathrm{FPU} / \mathrm{ml})$ & n.d. & \\
TrAXE & $0.1 \mu \mathrm{M}$ & $96.8 \pm 0.1$ & n.d. ${ }^{\text {d }}$ \\
TrXG & $0.1 \mu \mathrm{M}$ & $29.0 \pm 9.4$ & n.d. ${ }^{d}$ \\
Lichenase & $0.1 \mu \mathrm{M}$ & $45.0 \pm 4.2$ & n.d. ${ }^{d}$ \\
\hline
\end{tabular}

anhibitory power was measured for $\operatorname{TrCel7A}$ on MUL substrate.

${ }^{\mathrm{b}} \mathrm{IOS}$ at $100 \mu \mathrm{M}$ were treated with the indicated enzyme at $35^{\circ} \mathrm{C}$ for $2 \mathrm{~h}$.

${ }^{\mathrm{C}}$ The LF in its original concentration (Table 2) was treated with the indicated enzyme at $35^{\circ} \mathrm{C}$ for $2 \mathrm{~h}$.

${ }^{\mathrm{d}}$ Not determined.

'Thermomix contains Cel7A from Acremonium thermophilum, Cel6A from Chaetomium thermophilum, and EG, $\beta$-glucosidase, and xylanase from

Thermoascus aurantiacus [55]. 
degrading IOS is apparently due to their inherent hemicellulase activity [45,52-54]. The absence of the effect of TrAXE treatment suggests that the acetyl groups in XOS do not affect the binding to $\operatorname{Tr}$ Cel7A or that the amount of acetyl groups in XOS was too low to reveal a significant effect upon their removal. Owing to the fact that the enzymes were able to degrade IOS, one may refer to IOS as poor substrates and not as true inhibitors. Concerning $\operatorname{Tr}$ Cel7A, we still prefer to use the term "inhibitor". Although $\operatorname{Tr}$ Cel7A was able to reduce the inhibitory power of IOS by approximately 70\% (Table 4), this effect was observed using "harsh" conditions of IOS treatment (the IOS to $\operatorname{TrCel7A}$ ratio was $5 / 1$ on a mole basis). Under more "conventional" conditions, such as in inhibition studies in which the concentration of $\operatorname{TrCel7A}$ was in the nanomolar range, no degradation of IOS was observed, even after incubation for 2 days. A binary mixture of TaXyn10A and N188BG was also used for the treatment of IOS, and in this case, approximately $95 \%$ of the inhibitory power against $\operatorname{Tr}$ Cel7A was eliminated. This is consistent with the specificities of the enzymes and the proposed oligosaccharide composition of the IOS (Figure 5). To reveal the relative contribution of XOS and GOS to the total inhibitory power of IOS, we treated IOS with TaXyn10A or N188BG by varying the enzyme concentrations over three orders of magnitude. In the region of low enzyme concentrations, there was a sharp decrease in the inhibitory power of IOS with increasing enzyme concentration (Figure 8). A further increase in the enzyme concentration resulted in a more shallow and almost linear decrease in the inhibitory power of IOS. We speculate that for both enzymes, IOS can be regarded as a mixture of good and poor substrates. The good substrates are already rapidly degraded at low enzyme concentrations,

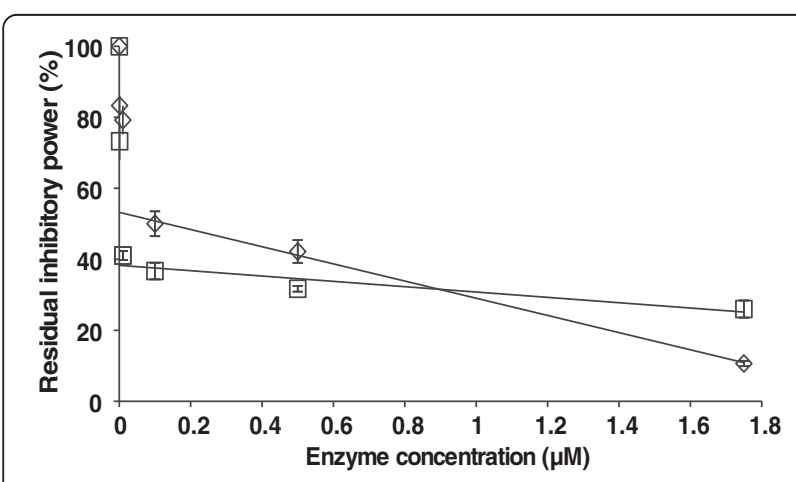

Figure 8 Treatment of IOS with TaXyn10 and N188BG. IOS $(100 \mu \mathrm{M})$ were treated with TaXyn10 $(\diamond)$ or N188BG () in $50 \mathrm{mM}$ sodium acetate buffer, $\mathrm{pH} 5.0$, containing BSA $\left(0.1 \mathrm{~g} \mathrm{l}^{-1}\right)$ at $35^{\circ} \mathrm{C}$ for $2 \mathrm{~h}$. The residual inhibitory power of IOS (as a\% of that of nontreated IOS) against TrCel7A on MUL is plotted as function of the enzyme concentration used for IOS treatment. The solid lines are from the linear regression analysis of the IOS degradation curve regions at higher enzyme concentrations $(0.1-1.75 \mu \mathrm{M})$. whereas further increases in the enzyme concentration reveal the slow degradation of poor substrates. Linear extrapolation of the slow degradation phase to the $y$-axis should thus reveal the relative contribution of a poor substrate to the total inhibitory power of IOS (Figure 8). In this way, we found that the contribution of a poor substrate was approximately $60 \%$ and $40 \%$ for TaXyn10A and N188BG, respectively. By assuming that XOS are good substrates for TaXyn10A and N188BG preferentially degrades GOS, we propose that the relative contribution of XOS and GOS to the inhibitory power of IOS is $40 \%$ and $60 \%$, respectively. Considering that the Xyl to Glc ratio in IOS was $5 / 1$ (Figure 3B), one may deduce that GOS are more than 5 times stronger inhibitors for $\operatorname{TrCel7A}$ than XOS.

Reducing the inhibitory power of the entire LF against $\operatorname{Tr}$ Cel7A by enzymatic treatment was also studied. As in the case of IOS, the most efficient individual enzyme component here was $\operatorname{Tr}$ Cel7B (Table 4). In contrast, whereas TaXyn10A was efficient in reducing the inhibitory power of IOS, the enzyme was rather inefficient in doing so with the LF. With all enzymes tested, the efficiency of reducing the inhibitory power of the LF was worse than that of IOS. This apparently reflects the more complex nature of inhibitory compounds in the LF. In addition to IOS, the LF may contain other inhibitors of $\operatorname{Tr}$ Cel7A that cannot be degraded by the enzymes. It may also be that the LF contains inhibitors for the enzymes used for its treatment so that the degradation of IOS in the LF is hampered. Two cellulase mixtures, Celluclast/Novozymes ${ }^{\circ} 188$ and the mixture of cellulases referred to as Thermomix [55] that was developed during the EU FP7 funded project HYPE, were also used for the treatment of the LF. Both mixtures were better than any individual enzyme components, but Thermomix outperformed the conventional Celluclast/ Novozymes ${ }^{\circ} 188$ mixture in reducing the inhibitory strength of the LF against $\operatorname{Tr}$ Cel7A (Table 4). It must be noted, however, that although the inhibitory power of the LF was greatly reduced by enzyme treatment, the remaining inhibitory power was still strong enough to silence $\operatorname{TrCel7A}$. Recall that whereas treatment of the LF reduces its inhibitory power by a factor of approximately 100 , the 10,000-fold diluted LF halved the activity of $\operatorname{Tr} \mathrm{Cel} 7 \mathrm{~A}$ on MUL (Figure 1B). Thus, the strong inhibition of cellulases by IOS reported here may be responsible for the poor enzymatic conversion of the whole slurries from the hydrothermal pretreatment of lignocellulose compared with that of the separated solid fractions [23,56-58]. However, poor conversion of whole slurries has also been observed for lignocelluloses pretreated using an acid catalyst, conditions that favor the degradation of hemicellulose [58-61]. Apparently, the oligosaccharides are not the sole determinants of the poor conversion of whole slurries, and the subject requires more study. The washing of solids after 
pretreatment increases the water consumption and is not economically feasible. Furthermore, a portion of the LF that is entrapped in the pores in pretreated solids will be transferred to the hydrolysis tank even after the washing of solids [62]. Although there may be other inhibitors beside IOS, our results suggest that the optimization of enzyme mixtures for better alleviation of the inhibition by IOS or pretreatment regimes that minimize the production of IOS may lead to better economics for the lignocelluloseto-ethanol process.

\section{Conclusions}

Here, we separated and identified strong cellulase inhibitors from the liquid fraction of the hydrothermal pretreatment of wheat straw. The inhibitors were confirmed to be oligosaccharides (IOS) with a DP ranging from 7 to 16 . The IOS were composed of a mixture of XOS and GOS. We propose that XOS and GOS are fragments of the xylan backbone and mixed-linkage $\beta$-glucans, respectively. The IOS were approximately 100 times stronger inhibitors for $T$. reesei $\mathrm{CBHs}$ than cellobiose. The mechanistic interpretation of the strong inhibitory power of IOS may be that, by mimicking the structure of the cellulose chain, XOS and GOS bind to the active site of $\mathrm{CBH}$ through all glucose unit binding sites. Most of the tested cellulases and hemicellulases were able to slowly degrade IOS and reduce the inhibitory power of IOS and the liquid fraction to some extent. Although reduced by the enzyme treatment, the residual inhibitory power of IOS and the liquid fraction was strong enough to silence the major component of the $T$. reesei cellulase system, $\mathrm{CBH} \operatorname{Tr}$ Cel7A.

\section{Methods \\ Materials}

The LF was kindly provided by Jan Larsen from Inbicon (Fredericia, Denmark). Glucose, MUL, MUG, pNPL, Novozyme ${ }^{\oplus} 188$, Celluclast ${ }^{\oplus}$, and BSA were purchased from Sigma-Aldrich. The lichenase was from Megazyme (Bray, Ireland). Cellobiose ( $\geq 99 \%)$ was from Fluka. D-[U- $\left.{ }^{14} \mathrm{C}\right]$ glucose with a specific activity of $262 \mathrm{mCi} \mathrm{mmol}^{-1}$ was from Hartmann Analytic GmbH. The scintillation cocktail was from Merck.

\footnotetext{
${ }^{14} \mathrm{C}$-cellulose substrates

${ }^{14} \mathrm{C}$-BC was prepared by laboratory fermentation of the Gluconobacter xylinum strain ATCC 53582 in the presence of a $\left[\mathrm{U}_{-}{ }^{14} \mathrm{C}\right]$ glucose carbon source $[63,64] .{ }^{14} \mathrm{C}-\mathrm{BC}$ had a specific activity of $450,000 \mathrm{DPM} \mathrm{mg} \mathrm{m}^{-1} \cdot{ }^{14} \mathrm{C}$-amorphous cellulose was prepared from ${ }^{14} \mathrm{C}$-bacterial microcrystalline cellulose by dissolution and regeneration from phosphoric acid [63]. The total concentration of cellulose was determined by the anthrone-sulfuric acid method.
}

\section{Enzymes}

$\operatorname{TrCel7A}, \operatorname{TrCel6A}, \operatorname{TrCel7B}, \operatorname{Tr} C e l 5 \mathrm{~A}$, and $\operatorname{TrCel12A}$ were purified from the culture filtrate of $T$. reesei QM 9414 as described previously [65-68]. N188BG was purified from Novozyme 188 according to [69]. The culture filtrate containing TaXyn10A heterologously expressed in the $T$. reesei strain lacking the genes of four major cellulases was kindly provided by Terhi Puranen from Roal Oy (Rajamäki, Finland). For purification of TaXyn10A, the above culture filtrate was heat treated in $50 \mathrm{mM}$ sodium phosphate buffer with a $\mathrm{pH}$ of 6.0 for $2 \mathrm{~h}$ at $60^{\circ} \mathrm{C}$ to sediment the background $T$. reesei enzymes [49]. Thermomix was also kindly provided by Terhi Puranen from Roal Oy (Rajamäki, Finland). The purified $\operatorname{TrXG}(\operatorname{Tr}$ Cel74A) and TrAXE were gifts from Matti Siika-aho from VTT (Espoo, Finland). The lichenase (Megazyme) was used as purchased.

\section{Separation and purification of IOS from the LF}

Before its application to the SEC column (Toyopearl HW40-F), the LF was centrifuged $(10,000 \times g)$ and pressed through a $0.2 \mu \mathrm{m}$ PVDF filter. SEC was performed using the ÄKTA Explorer chromatography system (GE Healthcare) at $4^{\circ} \mathrm{C}$. The column was equilibrated and eluted with water at a flow rate of $0.5 \mathrm{ml} \mathrm{min}^{-1}$. The fractions $(2.5 \mathrm{ml})$ were analyzed for the concentration of reducing groups using the modified BCA method [33,63] and for the inhibitory strength against $\operatorname{TrCel7A}$ on MUL. The fractions from SEC were also analyzed by HPLC. HPLC was performed using a Prominex HPLC system (Shimadzu) equipped with an Aminex HPX-87P (BioRad, $5 \mu \mathrm{m}$, $250 \mathrm{~mm} \times 7.8 \mathrm{~mm}$ ) column and a refractive index detector RID-10A (Shimadzu). The column temperature was kept at $80^{\circ} \mathrm{C}$, the flow rate was $0.6 \mathrm{ml} \mathrm{min}^{-1}$, and the eluent was water. The fractions from HPLC $(0.3 \mathrm{ml})$ were also collected and analyzed for the reducing groups and for the inhibitory strength against $\operatorname{TrCel7A}$ on MUL. Selected fractions from SEC were pooled, concentrated under reduced pressure, and purified on HPLC using the abovedescribed conditions. HPLC fractions with retention times between 8-10 min were pooled, concentrated under reduced pressure, and stored at $-18^{\circ} \mathrm{C}$ before use. This HPLC purified material is referred to as IOS throughout the study.

\section{Characterization of IOS}

Determination of the monosaccharide composition of IOS was performed essentially as described in [70]. IOS were autoclaved in $4 \%$ sulfuric acid $\left(1 \mathrm{~atm}, 121^{\circ} \mathrm{C}\right)$ for $3 \times 20 \mathrm{~min}$. Autoclaved samples were neutralized to $\mathrm{pH} 5-6$ by the addition of $\mathrm{CaCO}_{3}$. Precipitate was separated by centrifugation, and aliquots of supernatant were analyzed by HPLC. Monosaccharide standards were treated similarly to account for the sugar recovery [70]. The recovery of monosaccharide standards was above $90 \%$. 
Offline ESI-MS measurements were performed on an LTQ-Orbitrap classic mass spectrometer (Thermo Electron, Bremen, Germany) equipped with a nanoelectrospray ion source (Proxeon, Odense, Denmark) using Proxeon medium nanospray needles. A $5 \mu \mathrm{l}$ sample of IOS $(100 \mu \mathrm{M})$ in $10 \mathrm{mM}$ ammonium acetate ( $\mathrm{pH}$ 5) was introduced into the LTQ Orbitrap mass spectrometer operating at a $180^{\circ} \mathrm{C}$ capillary temperature, a $105.0 \mathrm{~V}$ tube lens voltage, and a $1.0 \mathrm{kV}$ needle voltage. Spectra (10 scans) were acquired in positive ion mode in profile $(\mathrm{m} / \mathrm{z} 500-2000)$ with a resolution of 100000 FWHM.

For deacetylation, IOS were incubated in $50 \mathrm{mM} \mathrm{NaOH}$ at $4^{\circ} \mathrm{C}$ overnight. The $\mathrm{pH}$ was adjusted to 6.0 by adding $0.5 \mathrm{M}$ acetic acid. Deacetylated and neutralized IOS were purified by HPLC (see purification of IOS) before ESI-MS analysis.

\section{Inhibition of $\operatorname{TrCel7A}$ and $\operatorname{TrCel7B}$ on MUL}

All experiments were performed in $1.5 \mathrm{ml}$ microcentrifuge tubes in $50 \mathrm{mM}$ sodium acetate (containing BSA, $0.1 \mathrm{~g} \mathrm{l}^{-1}$ ) at $\mathrm{pH} 5$ and $35^{\circ} \mathrm{C}$. The concentration of MUL was $5 \mu \mathrm{M}$ and $20 \mu \mathrm{M}$ in the case of experiments with $\operatorname{Tr}$ Cel7A and $\operatorname{Tr}$ Cel7B, respectively, and that of the inhibitor was varied as appropriate. Reactions were initiated by the addition of the enzyme to a final concentration of $10 \mathrm{nM}$ and stopped by the addition of $1.0 \mathrm{M}$ ammonium hydroxide (10\% of the total volume). The released MU was quantified by the fluorescence using a Hitachi F-4500 fluorimeter with excitation and emission wavelengths set to $360 \mathrm{~nm}$ and $450 \mathrm{~nm}$, respectively. The hydrolysis time was selected so that all rates of MU liberation correspond to the initial rates.

\section{Binding of IOS to cellulose}

IOS (0-100 $\mu \mathrm{M}$ on a reducing groups basis) were incubated with ${ }^{14} \mathrm{C}$-cellulose in $50 \mathrm{mM}$ sodium acetate buffer (containing BSA, $0.1 \mathrm{~g} \mathrm{l}^{-1}$ ) at $\mathrm{pH} 5$ and $35^{\circ} \mathrm{C}$ for $30 \mathrm{~min}$. The concentration of ${ }^{14} \mathrm{C}$-BC and ${ }^{14} \mathrm{C}$-amorphous cellulose was $0.25 \mathrm{~g} \mathrm{l}^{-1}$ and $0.5 \mathrm{~g} \mathrm{l}^{-1}$, respectively. Cellulose was separated by centrifugation, and supernatants were analyzed for their inhibitory strength against $\operatorname{TrCel7A}$ on MUL, as described above. The concentration of IOS in the supernatant was calculated from the inhibitory strength and the $\mathrm{IC}_{50}$ value of $0.31 \mu \mathrm{M}$ for IOS inhibition of $\operatorname{TrCel7A}$ using Equation 2. The concentration of IOS bound to cellulose was found as the difference between the total concentration of IOS and that in the supernatant.

\section{Inhibition of cellulases on ${ }^{14} \mathrm{C}$-cellulose}

All experiments were performed in $50 \mathrm{mM}$ sodium acetate buffer, pH 5.0, containing BSA $\left(0.1 \mathrm{~g} \mathrm{l}^{-1}\right)$ at $35^{\circ} \mathrm{C}$. Inhibition of $\operatorname{TrCel7A}$ was assessed by following the synergistic hydrolysis of ${ }^{14} \mathrm{C}-\mathrm{BC}$. For that, ${ }^{14} \mathrm{C}-\mathrm{BC}\left(0.25 \mathrm{~g} \mathrm{l}^{-1}\right)$ was pre-incubated (without stirring) with IOS at selected concentrations at $35^{\circ} \mathrm{C}$ for $30 \mathrm{~min}$. Hydrolysis was initiated by the addition of the mixture of $\operatorname{Tr}$ Cel7 A and $\operatorname{Tr}$ Cel5A to the final concentrations of $0.25 \mu \mathrm{M}$ and $0.025 \mu \mathrm{M}$, respectively. In the case of experiments with no added IOS, the reaction mixtures were supplied with N188BG $(0.06 \mu \mathrm{M})$. At selected times, $0.2 \mathrm{ml}$ aliquots were withdrawn and added to $20 \mu \mathrm{l} 1 \mathrm{M} \mathrm{NaOH}$ to stop the reaction. Residual cellulose was separated by centrifugation ( $2 \mathrm{~min}$, $10^{4} \times \mathrm{g}$ ), and radioactivity in the supernatant was quantified using a liquid scintillation counter. The degree of cellulose degradation was found from the ratio of radioactivity in the supernatant to the total radioactivity in the hydrolysis mixture. In the case of the inhibition of $\operatorname{TrCel6A}$, the same procedure and conditions were followed, except that $\operatorname{Tr}$ Cel5A was omitted.

IOS inhibition of EGs was assessed on ${ }^{14} \mathrm{C}$-amorphous cellulose. ${ }^{14} \mathrm{C}$-amorphous cellulose $\left(0.5 \mathrm{~g} \mathrm{l}^{-1}\right)$ was preincubated (with shaking at $700 \mathrm{rpm}$ ) with IOS at selected concentrations at $35^{\circ} \mathrm{C}$ for $30 \mathrm{~min}$. Hydrolysis was initiated by the addition of EG to a final concentration of $2.5 \mathrm{nM}$, $5.0 \mathrm{nM}$, and $50 \mathrm{nM}$ for $\operatorname{Tr}$ Cel7B, $\operatorname{Tr}$ Cel5A, and $\operatorname{Tr}$ Cel12A, respectively. The rest of the procedure was identical to that described above for CBHs.

\section{Treatment of IOS and LF with enzymes}

All of the experiments were performed in $50 \mathrm{mM}$ sodium acetate buffer, $\mathrm{pH} 5.0$, containing BSA $\left(0.1 \mathrm{~g} \mathrm{l}^{-1}\right)$ at $35^{\circ} \mathrm{C}$. IOS (100 $\mu \mathrm{M}$ on a reducing groups basis) were treated with different enzymes for $2 \mathrm{~h}$. Reactions were stopped by heating at $100^{\circ} \mathrm{C}$ for $20 \mathrm{~min}$. Heat-inactivated enzymes were pelleted by centrifugation ( $3 \mathrm{~min}, 10^{4} \times \mathrm{g}$ ), and aliquots of supernatants were used to quantify the residual inhibitory power against $\operatorname{Tr}$ Cel7A on MUL (see inhibition of $\operatorname{TrCel7A}$ on MUL). Enzymes treated identically but without the presence of IOS were used for background measurements in the determination of the activity of $\operatorname{TrCel7A}$ on MUL. In the case of the treatment of the LF, the remaining solids in the LF were separated by centrifugation $(10,000 \times g)$ and filtration through a $0.2 \mu \mathrm{m}$ PVDF filter. The concentration of the LF in the enzymatic treatment was as provided (Table 2). To maintain its original concentration, the volume of the LF was reduced using a vacuum concentrator followed by the addition of enzymes to restore the original volume of the LF. The following enzymes were used in the treatment of IOS and/or the LF: $\operatorname{TrCel7A}(21 \mu \mathrm{M}), \operatorname{Tr}$ Cel6A $(7 \mu \mathrm{M}), \operatorname{Tr}$ Cel7B $(3.5 \mu \mathrm{M})$, $\operatorname{TrCel5A}(3.5 \mu \mathrm{M}), \operatorname{Tr}$ Cel12A $(3.5 \mu \mathrm{M})$, N188BG $(1.75 \mu \mathrm{M})$, TaXyn10A (1.75 $\mu \mathrm{M}), \operatorname{TrAXE}(0.1 \mu \mathrm{M}), \operatorname{TrXG}(0.1 \mu \mathrm{M})$, and lichenase $(0.1 \mu \mathrm{M})$. Cellulase mixtures were loaded on an activity (FPU/CBU, for Celluclast/Novozyme ${ }^{\circledR} 188$ ) or on a mg protein (for Thermomix) basis. In the case of the treatment of IOS with N188BG and TaXyn10A, a series with varying enzyme concentrations (between $1.0 \mathrm{nM}$ and $1.75 \mu \mathrm{M})$ was also made. 
In the case of the initial assessment of the inhibitory power of the LF (data in Figure 1), the LF (with the $\mathrm{pH}$ adjusted to $\mathrm{pH} 5$ by the addition of $0.5 \mathrm{M}$ sodium acetate buffer) was treated with $0.1 \mu \mathrm{M}$ N188BG for $48 \mathrm{~h}$ before the inhibition studies. For the acid treatment, the LF was incubated with $2 \%$ sulfuric acid at $121^{\circ} \mathrm{C}$ for $20 \mathrm{~min}$, followed by neutralization with $\mathrm{NaOH}$ before inhibition studies on ${ }^{14} \mathrm{C}$-BC (Figure 1A).

\section{Additional file}

Additional file 1: Figure S1. Time courses of the hydrolysis of ${ }^{14} \mathrm{C}$-celluloses in the absence and presence of IOS.

\section{Abbreviations}

Ac: Acetyl; Ara: Arabinose; AXE: Acetyl-xylan esterase, BSA, Bovine serum albumin; CB: Cellobiose; ${ }^{14} \mathrm{C}-\mathrm{BC}:{ }^{14} \mathrm{C}$-labeled bacterial cellulose; $\mathrm{CBH}$ : Cellobiohydrolase; $\mathrm{D}_{\mathrm{IOS}}$ : Degree of conversion in the presence of IOS: $\mathrm{D}_{\mathrm{IOS}=0}$ : Degree of conversion in the absence of IOS; DM: Dry matter, DP, Degree of polymerization; EG: Endoglucanase; ESI-MS: Electrospray ionization mass spectroscopy; Glc: Glucose; GOS: Gluco-oligosaccharides; IOS: Inhibitory oligosaccharides; LF: Liquid fraction from hydrothermal pretreatment of wheat straw; MU: 4-methylumbelliferone; MUL: 4-methylumbelliferyl- $\beta$-lactoside; N188BG: $\beta$-glucosidase purified from Novozyme ${ }^{\circledast 188, ~ p N P L, ~ p a r a-n i t r o p h e n o l e-~}$ $\beta$-lactoside; SEC: Size exclusion chromatography; TaXyn10A: Xylanase from Thermoascus aurantiacus; Tr. Trichoderma reesei; XG: Xyloglucanase; XOS: Xylo-oligosaccharides; Xyl: Xylose.

\section{Competing interests}

The authors declare that they have no competing interests.

\section{Authors' contributions}

All authors designed and performed the experiments. RK and PV wrote the paper. All authors read and approved the final manuscript.

\section{Acknowledgements}

This work was funded by the EU Commission (FP7/2007-2013, grant agreement no. 213139) and the Estonian Science Foundation (grant no 9227). Jan Larsen from Inbicon (Fredericia, Denmark) is acknowledged for the LF. We are grateful to Terhi Puranen from Roal Oy (Rajamäki, Finland) for the TaXyn10A and Thermomix and Matti Siika-Aho from VTT (Espoo, Finland) for TrXG and TrAXE. Lauri Peil from the University of Edinburgh (UK) and Triin Tammsalu and Liisa Arike from the University of Tartu are acknowledged for the help with ESI-MS. Silja Kuusk from the University of Tartu is acknowledged for critical reading.

Received: 3 June 2013 Accepted: 13 September 2013 Published: 21 September 2013

\section{References}

1. Ragauskas AJ, Williams CK, Davison BH, Britovsek G, Cairney J, Eckert CA, Frederick WJ Jr, Hallet JP, Leak DJ, Liotta CL, Mielenz JR, Murphy R, Templer $\mathrm{R}$, Tschaplinski T: The path forward for biofuels and biomaterials. Science 2006, 311:484-489.

2. Vanholme R, Demedts B, Morreel K, Ralph J, Boerjan W: Lignin Biosynthesis and Structure. Plant Physiol 2010, 153:895-905.

3. Ding S-Y, Liu Y-S, Zeng Y, Himmel ME, Baker JO, Bayer EA: How does plant cell wall nanoscale architecture correlate with enzymatic digestibility? Science 2012, 338:1055-1059.

4. Scheller HV, Ulvskov P: Hemicelluloses. Annu Rev Plant Biol 2010, 61:263-289.

5. Ebringerová A: Structural diversity and application potential of hemicelluloses. Macromol Symp 2006, 232:1-12.

6. Appeldoorn MM, Kabel MA, Van Eylen D, Gruppen H, Schols HA Characterization of oligomeric xylan structures from corn fiber resistant to pretreatment and simultaneous saccharification and fermentation. J Agric Food Chem 2010, 58:11294-11301.
7. Burton RA, Gidley MJ, Fincher GB: Heterogeneity in the chemistry, structure and function of plant cell walls. Nat Chem Biol 2010, 6:724-732

8. Lynd LR, Weimer PJ, van Zyl WH, Pretorius IS: Microbial cellulose utilization: fundamentals and biotechnology. Microbiol Mol Biol Rev 2002, 66:506-577

9. Himmel ME, Ding SY, Johnson DK, Adney WS, Nimlos MR, Brady JW, Foust TD: Biomass recalcitrance: engineering plants and enzymes for biofuels production. Science 2007, 315:804-807.

10. Modenbach AA, Nokes SE: The use of high-solids loadings in biomass pretreatment - a review. Biotechnol Bioeng 2012, 109:1430-1442.

11. Pu Y, Hu F, Huang F, Davison BH, Ragauskas AJ: Assessing the molecular structure basis for biomass recalcitrance during dilute acid and hydrothermal pretreatments. Biotechnol Biofuels 2013, 6:15.

12. Petersen $\varnothing \mathrm{M}$, Larsen J, Thomsen $\mathrm{MH}$ : Optimization of hydrothermal pretreatment of wheat straw for production of bioethanol at low water consumption without addition of chemicals. Biomass Bioenergy 2009, 33:834-840.

13. Thomsen $\mathrm{MH}$, Thygesen $\mathrm{A}$, Thomsen $\mathrm{AB}$ : Hydrothermal treatment of wheat straw at pilot plant scale using a three-step reactor system aiming at high hemicellulose recovery, high cellulose digestibility and low lignin hydrolysis. Bioresour Technol 2008, 99:4221-4228.

14. Gnansounou E: Production and use of lignocellulosic bioethanol in Europe: Current situation and perspectives. Bioresour Technol 2010, 101:4842-4850.

15. Holopainen-Mantila U, Marjamaa K, Merali Z, Käsper A, de Bot $P$ Jääskeläinen A-S, Waldron K, Kruus K, Tamminen T: Impact of hydrothermal pre-treatment to chemical composition, enzymatic digestibility and spatial distribution of cell wall polymers. Bioresour Technol 2013, 138:156-162.

16. Hansen MAT, Hidayat BJ, Mogensen KK, Jeppesen MD, Jorgensen B, Johansen KS, Thygesen LG: Enzyme affinity to cell types in wheat straw (Triticum aestivum L.) before and after hydrothermal pretreatment. Biotechnol Biofuels 2013, 6:54

17. Jönsson LJ, Alriksson B, Nilvebrant NO: Bioconversion of lignocellulose: inhibitors and detoxification. Biotechnol Biofuels 2013, 6:16.

18. Xiros C, Vafiadi C, Paschos T, Christakopoulos P: Toxicity tolerance of Fusarium oxysporum towards inhibitory compounds formed during pretreatment of lignocellulosic materials. J Chem Technol Biotechnol 2011, 86:223-230.

19. Wang $X$, Yomano LP, Lee JY, York SW, Zheng H, Mullinnix MT, Shanmugam $K T$, Ingram LO: Engineering furfural tolerance in Escherichia coli improves the fermentation of lignocellulosic sugars into renewable chemicals. Proc Natl Acad Sci U S A 2013, 110:4021-4026.

20. Selig MJ, Knoshaug EP, Adney WS, Himmel ME, Decker SR: Synergistic enhancement of cellobiohydrolase performance on pretreated corn stover by addition of xylanase and esterase activities. Bioresour Technol 2008, 99:4997-5005.

21. Qing Q, Yang B, Wyman CE: Xylooligomers are strong inhibitors of cellulose hydrolysis by enzymes. Bioresour Technol 2010, 101:9624-9630.

22. Qing Q, Wyman CE: Supplementation with xylanase and $\beta$-xylosidase to reduce xylo-oligomer and xylan inhibition of enzymatic hydrolysis of cellulose and pretreated corn stover. Biotechnol Biofuels 2011, 4:18.

23. Yang B, Dai Z, Ding S-Y, Wyman CE: Enzymatic hydrolysis of cellulosic biomass. Biogeosciences 2011, 2:421-450.

24. Um B-H, van Walsum GP: Effect of pretreatment severity on accumulation of major degradation products from dilute acid pretreated corn stover and subsequent inhibition of enzymatic hydrolysis of cellulose. Appl Biochem Biotechnol 2012, 168:406-420.

25. Duarte GC, Moreira LRS, Jaramillo PMD, Filho EXF: Biomass-derived inhibitors of holocellulases. Bioenerg Res 2012, 5:768-777.

26. Teugjas H, Väljamäe P: Product inhibition of cellulases studied with ${ }^{14} \mathrm{C}$ labeled cellulose substrates. Biotechnol Biofuels 2013, 6:104.

27. Gruno M, Väljamäe P, Pettersson $G$, Johansson G: Inhibition of the Trichoderma reesei cellulases by cellobiose is strongly dependent on the nature of the substrate. Biotechnol Bioeng 2004, 86:503-511.

28. Murphy L, Bohlin C, Baumann MJ, Olsen SN, Sorensen TH, Anderson L, Borch K, Westh P: Product inhibition of five Hypocrea jecorina cellulases. Enzyme Microb Technol 2013, 52:163-169.

29. Baumann MJ, Borch K, Westh P: Xylan oligosaccharides and cellobiohydrolase I ( $\operatorname{rrCel7A}$ ) interaction and effect on activity. Biotechnol Biofuels 2011, 4:45 
30. Zhang J, Viikari L: Xylo-oligosaccharides are competitive inhibitors of cellobiohydrolase I from Thermoascus aurantiacus. Bioresour Technol 2012, 117:286-291.

31. Zhang J, Tang M, Viikari L: Xylan inhibit enzymatic hydrolysis of lignocellulosic materials by cellulases. Bioresour Technol 2012, 121:8-12

32. Burton RA, Fincher GB: Current challenges in cell wall biology in the cereals and grasses. Front Plant Sci 2012, 3:130.

33. Zhang $Y H$, Lynd LR: Determination of the number-average degree of polymerization of cellodextrins and cellulose with application to enzymatic hydrolysis. Biomacromolecules 2005, 6:1510-1515.

34. Staudte RG, Woodward JR, Fincher GB, Stone BA: Water-soluble $(1 \rightarrow 3)$, $(1 \rightarrow 4)-\beta-d-g l u c a n s$ from barley (Hordeum vulgare) endosperm. III. Distribution of cellotriosyl and cellotetraosyl residues. Carbohydr Polym 1983, 3:299-312

35. Voutilainen SP, Puranen T, Siika-Aho M, Lappalainen A, Alapuranen M, Kallio J, Hooman S, Viikri L, Vehmaanpera J, Koivula A: Cloning, expression, and characterization of novel thermostable family 7 cellobiohydrolases. Biotechnol Bioeng 2008, 101:515-528.

36. Brumer H III, Zhou Q, Baumann MJ, Carlsson K, Teeri TT: Activation of crystalline cellulose surfaces through the chemoenzymatic modification of xyloglucan. J Am Chem Soc 2004, 126:5715-5721.

37. Kabel MA, Van den Borne H, Vincken J-P, Voragen AGJ, Schols HA: Structural differences of xylans affect their interaction with cellulose. Carbohydr Polym 2007, 69:91-105.

38. Zhang $\mathrm{Q}$, Brumer $\mathrm{H}$, Ågren $\mathrm{H}, \mathrm{Tu} \mathrm{Y}$ : The adsorption of xyloglucan on cellulose: effects of explicit water and side chain variation. Carbohydr Res 2011, 346:2595-2602.

39. Kohnke T, Ostlund A, Brelid H: Adsorption of arabinoxylan on cellulosic surfaces: influence of the degree of substitution and substitution pattern on adsorption characteristics. Biomacromolecules 2011, 12:2633-2641.

40. Mazeau K, Charlier L: The molecular basis of the adsorption of xylans on cellulose surface. Cellulose 2012, 19:337-349.

41. Gu J, Catchmark JM: The impact of cellulose structure on binding interactions with hemicellulose and pectin. Cellulose 2013, 20:1613-1627.

42. Berlin A, Gilkes N, Kilburn D, Bura R, Markov A, Skomarovsky A, Okunev O, Gusakov A, Maximenko V, Gregg D, Sinitsyn A, Saddler J: Evaluation of novel fungal cellulase preparations for ability to hydrolyze softwood substrates - evidence for the role of accessory enzymes. Enzyme Microb Technol 2005, 37:175-184.

43. Kabel MA, Bos G, Zeevalking J, Voragen AGJ, Schols HA: Effect of pretreatment severity on xylan solubility and enzymatic breakdown of the remaining cellulose from wheat straw. Bioresour Technol 2007 98:2034-2042

44. Kumar R, Wyman CE: Effect of enzyme supplementation at moderate cellulase loadings on initial glucose and xylose release from corn stover solids pretreated by leading technologies. Biotechnol Bioeng 2009, 102:457-467.

45. Varnai A, Huikko L, Pere J, Siika-aho M, Viikari L: Synergistic action of xylanase and mannanase improves the total hydrolysis of softwood. Bioresour Technol 2011, 102:9096-9104.

46. Penttilä PA, Varnai A, Pere J, Tammelin T, Salmen L, Siika-aho M, Viikari L, Serimaa R: Xylan as limiting factor in enzymatic hydrolysis of nanocellulose. Bioresour Technol 2013, 129:135-141.

47. Kumar R, Wyman CE: Effect of xylanase supplementation of cellulase on digestion of corn stover solids prepared by leading pretreatment technologies. Bioresour Technol 2009, 100:4203-4213.

48. Qing Q, Wyman CE: Hydrolysis of different chain length xylooligomers by cellulase and hemicellulase. Bioresour Technol 2011, 102:1359-1366.

49. Zhang J, Tuomainen P, Siika-aho M, Viikari L: Comparison of the synergistic action of two thermostable xylanases from GH families 10 and 11 with thermostable cellulases in lignocellulose hydrolysis. Bioresour Technol 2011, 102:9090-9095.

50. Zhang J, Siika-aho M, Tenkanen M, Viikari L: The role of acetyl xylan esterase in the solubilization of xylan and enzymatic hydrolysis of wheat straw and giant reed. Biotechnol Biofuels 2011, 4:60.

51. Benkö Z, Siika-aho M, Viikari L, Reczey K: Evaluation of the role of xyloglucanase in the enzymatic hydrolysis of lignocellulosic substrates. Enzyme Microb Technol 2008, 43:109-114.

52. Karlsson J, Siika-aho M, Tenkanen M, Tjerneld F: Enzymatic properties of the low molecular mass endoglucanases Cel12A (EG III) and Cel45A (EG V) of Trichoderma reesei. J Biotechnol 2002, 99:63-78.
53. Biely $P$, Vrsanska $M$, Claeyssens $M$ : The endo-1,4- $\beta$-glucanase I from Trichoderma reesei. Action on $\beta$-1,4-oligomers and polymers derived from D-glucose and D-xylose. Eur J Biochem 1991, 200:157-163.

54. Vlasenko E, Schülein M, Cherry J, Xu F: Substrate specificity of family 5, 6, 7, 9, 12, and 45 endoglucanases. Bioresour Technol 2010, 101:2405-2411.

55. Skovgaard PA, Jorgensen $\mathrm{H}$ : Influence of high temperature and ethanol on thermostable lignocellulolytic enzymes. J Ind Microbiol Biotechnol 2013, 40:447-456.

56. Tengborg C, Galbe M, Zacchi G: Reduced inhibition of enzymatic hydrolysis of steam-pretreated softwood. Enzyme Microb Technol 2001, 28:835-844.

57. Öhgren K, Bura R, Lesnicki G, Saddler J, Zacchi G: A comparison between simultaneous saccharification and fermentation and separate hydrolysis and fermentation using steam-pretreated corn stover. Process Biochem 2007, 42:834-839.

58. Studer MH, Brethauer S, DeMartini JD, McKenzie HL, Wyman CE: Cohydrolysis of hydrothermal and dilute acid pretreated Populus slurries to support development of a high-throughput pretreatment system. Biotechnol Biofuels 2011, 4:19.

59. Hodge DB, Karim MN, Schell DJ, MCMillan JD: Soluble and insoluble solids contributions to high-solids enzymatic hydrolysis of lignocellulose. Bioresour Technol 2008, 99:8940-8948.

60. McMillan JD, Jennings EW, Mohagheghi A, Zuccarello M: Comparative performance of precommercial cellulases hydrolyzing pretreated corn stover. Biotechnol Biofuels 2011, 4:29.

61. Luterbacher JS, Chew Q, Li Y, Tester JW, Walker LP: Producing concentrated solutions of monosaccharides using biphasic $\mathrm{CO}_{2}-\mathrm{H}_{2} \mathrm{O}$ mixtures. Energy Environ Sci 2012, 5:6990-7000.

62. Berson RE, Young JS, Hanley TR: Reintroduced solids increase inhibitor levels in a pretreated corn stover hydrolysate. Appl Biochem Biotechno 2006, 129-132:612-620.

63. Velleste R, Teugjas $H$, Väljamäe P: Reducing end-specific fluorescence labelled celluloses for cellulase mode of action. Cellulose 2010, 17:125-138.

64. Jalak J, Kurašin $M$, Teugjas $H$, Väljamäe P: Endo-exo synergism in cellulose hydrolysis revisited. J Biol Chem 2012, 287:28802-28815.

65. Håkansson U, Fägerstam L, Pettersson G, Andersson L: Purification and characterization of a low molecular weight 1,4-beta-glucan glucanohydrolase from the cellulolytic fungus Trichoderma reesei QM9414. Biochim Biophys Acta 1978, 524:385-392.

66. Bhikhabhai R, Johansson G, Pettersson G: Isolation of cellulolytic enzymes from Trichoderma reesei QM 9414. J Appl Biochem 1984, 6:336-345.

67. Saloheimo M, Lehtovaara P, Penttilä M, Teeri TT, Ståhlberg J, Johansson G, Pettersson G, Claeyssens M, Tomme P, Knowles JKC: EG III a new endoglucanase from Trichoderma reesei: the characterization of both gene and enzyme. Gene 1988, 63:11-21.

68. Kipper K, Väljamäe $P$, Johansson G: Processive action of cellobiohydrolase Cel7A from Trichoderma reesei is revealed as "burst" kinetics on fuorescent polymeric model substrates. Biochem J 2005, 385:527-535.

69. Sipos B, Benkö Z, Reczey K, Viikari L, Siika-aho M: Characterisation of specific activities and hydrolytic properties of cell-wall-degrading enzymes produced by Trichoderma reesei Rut C30 on different carbon sources. Appl Biochem Biotechnol 2010, 161:347-364.

70. Sluiter A, Hames B, Ruiz R, Scarlata C, Sluiter J, Templeton D: Determination of structural carbohydrates and lignin in biomass. Golden, CO: Laboratory analytical procedures, National Renewable Energy Laboratory; 2004.

doi:10.1186/1754-6834-6-135

Cite this article as: Kont et al:: Strong cellulase inhibitors from the hydrothermal pretreatment of wheat straw. Biotechnology for Biofuels 2013 6:135. 